\title{
Comparison Analysis of Anthocyanin Substances in various Plants for Testing Media of Formalin and Borax Content in Food
}

\author{
Neny Rochyani ${ }^{1}$ \\ ${ }^{1}$ Fisheries faculty, PGRI University, 30116 Palembang, Indonesia
}

\begin{abstract}
Anthocyanin substances found in plants are known could be able to indicate acidic and alkaline compounds which means it can indicate the presence of additives in various materials. Food is an important factor in human life as a basic need to grow and survive. The presence of foods containing formaldehyde and borax can endanger human health, therefore there is a need an effort and ingredients to identify the presence or absence of these substances. This can be done by making test equipment that is able to indicate food containing non-food additives. This study focused on comparative analysis of anthocyanin content in some plants to be used as food testing materials containing formalin and borax using filter paper, as well as knowing the effect of solvent variations on mass extraction of anthocyanins and yields. Testing using solvents, namely ethanol with variations, the test equipment is produced through extraction of plants and solvents which are then soaked in filter paper and dried so that they are absorbed therein. The test results show that the anthocyanin substance in all plant samples is good to be used as a test tool but the ipomea batatas L is better and the variation of solvent has a significant influence on the extraction of anthocyanin and rendemen, while the test media extracted using ethanol solvent variations can detect the formaldehyde content and borax well.
\end{abstract}

\section{Introduction}

The increasing demand for food products allows the development of the food production sector. On the other hand producers want the food products produced to last a long time to get high profits. This results in the emergence of many preservatives for food which aims to extend the storage time of a material. Formalin and Borax are one of the nonfood additives that are widely used by various groups in food preservation. However, there are still many people who do not understand the difference in the use of preservatives for food and non-food ingredients, so the use of borax and formalin will be increasingly used.

Formalin is a mixture of formaldehyde, methanol and water. The levels of formaldehyde in formalin are varied, between $20 \%-40 \%$. The acidity level is $\mathrm{pH} 4$ (acidic). Chemical compounds from formaldehyde are also called methanal or formalin, with the chemical formula H2CO. Initially Formaldehyde was synthesized by Aleksandr Butlerov in 1859, 
and was only identified by Hoffman in 1867. Borax is a mixture of high concentrations of mineral salts and has a $\mathrm{pH}$ of $\mathrm{pH} 9.5$ (alkaline). Another name is sodium biborat, sodium piroborate, sodium tetraborate. The use and consumption of food and beverages containing formalin and borax in the long term will have a bad impact on health, the danger of consuming food containing formaldehyde, among others, causes irritation of the mucous membranes that cause tears, dizziness, throat burning, aversion, able to increase acidity in the blood, shortness of breath, hyportemia, cancer, coma and even death. While the dangers of foods that contain borax include causing disturbances to the brain, liver and kidneys. In large amounts borax causes fever, anuria (no urine formation), coma, central nervous system disorders, depression, kidney damage, decreased blood pressure, fainting to death.

Based on the dangers of using formaldehyde and borax in food, it is mainly for the general public to need knowledge and information in ways and techniques that are easy to test the content, namely by the existence of a simple test equipment but able to indicate foods that contain non-food additives. Previous research studies have explained that anthocyanin substances found in plants can indicate acidic and alkaline compounds. Anthocyanin is a natural dye that is an antioxidant found in plants. More than 300 anthocyanin structures found have been identified naturally [1]. Anthocyanin is a pigment from the group of flavonoids which are water soluble, red to blue and widely distributed in plants. Especially found in fruits, yams and flowers, but also found in leaves [2].

The color that appears as a result of the anthocyanin depends on the level of acidity $(\mathrm{pH})$ of the surrounding environment so that this pigment can be used as a $\mathrm{pH}$ indicator. The colors are red $(\mathrm{pH} \mathrm{1)}$, reddish blue $(\mathrm{pH} 4)$, purple $(\mathrm{pH} 6)$, blue $(\mathrm{pH} 8)$, green $(\mathrm{pH} 12)$, and yellow (pH 13) [3].

Formalin has a $\mathrm{pH}$ of 4 which means acidic compounds while borax is alkaline with a $\mathrm{pH}$ of 9.5 , so if both substances are dripped on anthocyanin extracts which have a tendency of $\mathrm{pH}$ to be near neutral there will be discoloration. This color change is able to indicate the addition of formalin and borax compounds in food. By using media in the form of filter paper, the application of anthocyanin substances can occur effectively. Therefore, an analysis of the content of anthocyanic substances in various plants is important to know and further allows for the making of media tester using a variation of solvent concentrations with filter paper, that can detect the content of borax and formalin in food.

\section{Materials and Methods}

The research was carried out by conducting experiments in the laboratory. That is by making a media tester for formalin and borax contain on food by utilizing anthocyanin substances in several plants, namely, purple sweet potato (Ipomoea batatas L), beet tuber (beta vulgaris L), and duwet (Eugenia Jambloana) and filter paper. Anthocyanins from these plants are extracted by maceration extraction methods using alcohol as a solvents with various variations. Extraction and yield results using solvent concentration were measured by observation data and tested by ANOVA test, so that the the effect was known. Furthermore, the extraction results on the gardening were applied to the filter paper media, by soaking and then drying. Filter paper containing anthocyanin extract then used as a media tester for formalin and borax contain in food. The extraction solution in those various plants will be analyzed for its anthocyanin content (\% yield) while the test media produced will be tested for reactivity using formalin solution and borax solution. 


\subsection{Tools and Materials}

a. Tool

The tools used in this research are:

Table 1. Tools and Their uses

\begin{tabular}{|c|c|c|}
\hline No & Tool's name & Usefulness \\
\hline 1 & Measuring cup & $\begin{array}{l}\text { measure the volume of alcohol } \\
\text { and anthocyanin extract }\end{array}$ \\
\hline 2 & Petri dish & $\begin{array}{l}\text { accommodating a mixture of } \\
\text { anthocyanin extracts }\end{array}$ \\
\hline 3 & Knife & cutting materials \\
\hline 4 & Scissor & To cut the filter paper \\
\hline 5 & Erlenmeyer & accommodate fluid \\
\hline 6 & Spatula & $\mathrm{P}$ engaduk during extraction \\
\hline 7 & Filter paper & $\begin{array}{l}\text { refine and test media } \\
\text { formaldehyde and borax }\end{array}$ \\
\hline 8 & Splitter Funnels & $\begin{array}{l}\text { separating the fluid from the } \\
\text { dissolved solids. }\end{array}$ \\
\hline 9 & Mortal and pestle & smooth the sweet potato. \\
\hline 10 & Digital scales & measure mass. \\
\hline
\end{tabular}

b. Material

The materials used in this research are:

Table 2. Material and Its usefulness

\begin{tabular}{|c|c|c|}
\hline No & Material Name & Usefulness \\
\hline 1. & Sweet Potato & For the anthocyanin extract \\
\hline 2. & Alcohol $70 \%, 80 \%$ and $90 \%$ & $\begin{array}{c}\text { As solvent (solvent) to dissolve the anthocyanin substance in } \\
\text { purple sweet potato, beet and Duwet }\end{array}$ \\
\hline 3. & Water & For boiling purple sweet potatoes \\
\hline
\end{tabular}

\subsection{Procedure Research}

\subsubsection{Preparation Materials and Tools}

Sample Preparation

a. Clean each plant and boil until cooked and then drain.

b. Then the sample is weighed 50 grams

c. The plants that have been weighed are then cut or chopped small.

Solvent Preparation

The solvent used is ethanol with a concentration variation of $70 \%, 80 \%$, and $90 \%$. 


\subsubsection{Extraction Process}

Extracting plants with a variation on alcohols level using maseration extraction methods to obtain anthocyanin extracts from these plants. By inserting 50 grams of each plant and adding $100 \mathrm{ml}$ of ethanol into the measuring cup, then the extraction process is carried out for 45 - 60 minutes while stirring occasionally so that the purple pigment on the yam fades. After the extraction process, strain the alcohol solution has changed on color using filter paper. An alcohol that changed to purple indicate that anthocyanins in those plants have been extracted and mixed with solvents. At this stage the extracted solution is named Anthocyanin Crude Extract (CEA).

1. Immersion Process

a. The next step is to prepare filter paper with a length of $10 \mathrm{~cm}$ and $10 \mathrm{~cm}$ wide.

b. Place the CEA solution into the petri dish then dip the filter paper of the size that has been determined into the solution until smooth

2. Drying Process

Then dry in a temperature of 28-35 omC in a closed space for 2-3 days so that the mixture of CEA solution is absorbed perfectly on the filter paper. After drying, the last step is to cut the small filter paper with a size of $1.5 \mathrm{~cm} \times 2.5 \mathrm{~cm}$.

\section{Results and Discussions}

Of the various types of sweet potatoes, purple sweet potato is sweet potato with a considerable amount of anthocyanin pigment. This color is obtained from the flesh and skin. The total anthocyanin content varies in each plant and ranges from $20 \mathrm{mg} / 100 \mathrm{~g}$ to $600 \mathrm{mg} / 100 \mathrm{~g}$ wet weight. The total anthocyanin content of purple sweet potato is $519 \mathrm{mg}$ $/ 100 \mathrm{~g}$ of wet weight [4] [5]. For tubers, it is known that the anthocyanin content in each fruit is different between $25 \mathrm{mg} / 100 \mathrm{~g}$ Whereas for duwet plants it is known to contain anthocyanin at $230 \mathrm{mg} / 100 \mathrm{~g}$.

\subsection{Anthocyanin substances}

Anthocyanin is a water-soluble pigment which is naturally found in various types of plants. As the name implies, this pigment gives color to the flowers, tubers, fruits and leaves of plants, and has been widely used as a natural dye in various food products and various other applications. The color is given by anthocyanin thanks to its long conjugated double bond arrangement. This conjugated double bonding system is also capable of making anthocyanins as antioxidants with an antidote to free radicals. Anthocyanin is a sub-type of organic compounds from the flavonoid family and is a member of a larger group of compounds namely polyphenols. Some of the most commonly found anthocyanin compounds are pelargonidin, peonidin, cyanidine, malvidin, petunidine, and delfinidine. 


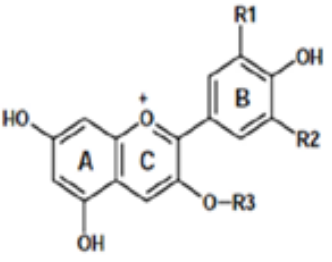

\begin{tabular}{lcc}
\multicolumn{1}{r}{ Antosianin } & $\mathrm{R} 1$ & $\mathrm{R2}$ \\
\hline Delfinidin & $\mathrm{OH}$ & $\mathrm{OH}$ \\
Petunidin & $\mathrm{OH}$ & $\mathrm{OCH}_{3}$ \\
Malvidin & $\mathrm{OCH}_{3}$ & $\mathrm{OCH}_{3}$ \\
Sianidin & $\mathrm{OH}$ & $\mathrm{H}$ \\
Peonidin & $\mathrm{OCH}_{3}$ & $\mathrm{H}$ \\
Pelargonidin & $\mathrm{H}$ & $\mathrm{H}$
\end{tabular}

Fig. 1. Anthocyanin Structure Formula

Factors that affect anthocyanin stability

a. pH

The color caused by anthocyanin depends on the level of acidity $(\mathrm{pH})$ of the surrounding environment so that this pigment can be used as a $\mathrm{pH}$ indicator. Color posed is red $(\mathrm{pH} 1-4)$, reddish blue ( $\mathrm{pH} 4-5)$, purple $(\mathrm{pH}$ 6), blue $(\mathrm{pH} 8-11)$, green $(\mathrm{pH} \mathrm{12})$, and yellow ( $\mathrm{pH} \mathrm{13).} \mathrm{To} \mathrm{obtain} \mathrm{the} \mathrm{desired} \mathrm{color,} \mathrm{anthocyanins} \mathrm{should} \mathrm{be} \mathrm{stored} \mathrm{using} \mathrm{buffer}$ solution with the appropriate $\mathrm{pH}$.

\section{b. Cation}

Partly cation, should be avoided because it can cause anthocyanin to blue color changes until pigment precipitation occurs. In addition, the surface of the copper, mild steel, and iron are also best avoided.

\section{c. Oxygen}

When dissolved in a solvent mixture, anthocyanin will be oxidized slowly.

\section{d. Sulfur dioxide ( $\mathrm{SO}_{2}$ )}

If sulfur dioxide reacting with anthocyanin will form a colorless product. The color change reaction is reversible so only by heating $\mathrm{SO}_{2}$ then the color will return as before.

\section{e. Protein}

When the anthocyanin source reacts with protein it will be formed steam or sediment. This event is more influenced by non pigments phenolic which react with proteins such as gelatin.

\section{f. Enzyme}

The use of some enzymes in food processing containing anthocyanins may result in the anthocyanin content in them being lost or reduced. This is partly due to the enzyme glucosidase which is in the preparation stage of the enzyme.

\subsection{Mass Extraction Results of Sweet Potatoes with Solvent Variations}

The following are the results of the observation of the extraction of anthocyanin substances in purple sweet potatoes that have been carried out, including data from the calculation of mass transfer and percent yield. 
Table 3. Results of purple sweet potato mass extraction with variations in ethanol solvent concentration.

\begin{tabular}{|c|c|c|c|c|c|}
\hline Solvent & $\begin{array}{c}\text { Concentrat } \\
\text { e }\end{array}$ & $\begin{array}{c}\text { Ipomea } \\
\text { Mass (gr) }\end{array}$ & $\begin{array}{c}\text { Solvent } \\
\text { Mass (gr) }\end{array}$ & $\begin{array}{c}\text { Residu } \\
\text { Massa (gr) }\end{array}$ & $\begin{array}{c}\text { CEA Solar } \\
\text { Mass(gr) }\end{array}$ \\
\hline \multirow{3}{*}{ Ethanol } & $70 \%$ & 50 & 79.79 & 48.14 & 81.65 \\
\cline { 2 - 6 } & $80 \%$ & 50 & 74.98 & 46.83 & 78.15 \\
\cline { 2 - 6 } & $90 \%$ & 50 & 74.39 & 45.26 & 79.13 \\
\hline
\end{tabular}

Table 4. Results of Beet mass extraction with variations in ethanol solvent concentration.

\begin{tabular}{|c|c|c|c|c|c|}
\hline \multirow{2}{*}{ Solvent } & $\begin{array}{c}\text { Concentrat } \\
\mathbf{e}\end{array}$ & $\begin{array}{c}\text { Ipomea } \\
\text { Mass (gr) }\end{array}$ & $\begin{array}{c}\text { Solvent } \\
\text { Mass (gr) }\end{array}$ & $\begin{array}{c}\text { Residu } \\
\text { Massa } \\
\text { (gr) }\end{array}$ & $\begin{array}{c}\text { CEA Solar } \\
\text { Mass(gr) }\end{array}$ \\
\hline \multirow{3}{*}{ Ethanol } & $70 \%$ & 50 & 75.76 & 45.54 & 74.65 \\
\cline { 2 - 6 } & $80 \%$ & 50 & 70.5 & 43.6 & 70.15 \\
\cline { 2 - 6 } & $90 \%$ & 50 & 70.8 & 40.25 & 70.10 \\
\hline
\end{tabular}

Table 5. Results of Duwet mass extraction with variations in ethanol solvent concentration.

\begin{tabular}{|c|c|c|c|c|c|}
\hline \multirow{2}{*}{ Solvent } & Concentrate & $\begin{array}{c}\text { Ipomea } \\
\text { Mass (gr) }\end{array}$ & $\begin{array}{c}\text { Solvent Mass } \\
\text { (gr) }\end{array}$ & $\begin{array}{c}\text { Residu } \\
\text { Massa } \\
\text { (gr) }\end{array}$ & $\begin{array}{c}\text { CEA } \\
\text { Solar } \\
\text { Mass(gr) }\end{array}$ \\
\hline \multirow{3}{*}{ Ethanol } & $70 \%$ & 50 & 70.70 & 48.15 & 75.65 \\
\cline { 2 - 6 } & $80 \%$ & 50 & 67.96 & 47.73 & 70.67 \\
\cline { 2 - 6 } & $90 \%$ & 50 & 65.38 & 47.28 & 70.22 \\
\hline
\end{tabular}

Based on the observational data, the test results can be seen that the extraction with variations in solvent concentration shows the condition of the solution mass will be greater in the experiment with the highest solvent concentration of $90 \%$. Mass extraction results of a solution of 79.12 gr with a mass of dregs of 45.26 gr. And the solvent mass is $74.39 \mathrm{gr}$. In sweet potatoes, also in bits of 70.10 mass of solution, $40.25 \%$ mass of pulp and solvent mass of $70.10 \%$. Whereas in the mass duwet the solution was $70.22 \%$, the mass of the waste was 47.28 and the solvent mass was $65.38 \%$.

The opposite thing happens at a low solvent concentration of $70 \%$. The test results show that with a low solvent concentration level, the extraction results are also low. Thus it can be concluded that the greater the solvent concentration, the higher the mass produced.

\subsection{Plant Extraction Result Extraction with Solvent Variations}

$$
\text { Rendemen }=\frac{\text { Weight before Ex }- \text { After Ex.x } 100}{\text { Weight before extraction }}
$$

Calculation of percent yield can be calculated using the equation above. From the data in table 4.1 above, the mass of anthocyanin substances obtained and percent yield of extraction results can be seen in the following table: 
Table 6. Extraction Result on mass with varying concentrations of ethanol solvent.

Sweet Potato

\begin{tabular}{|c|c|c|c|}
\hline solvent & concentrate & $\begin{array}{c}\text { Anthocyanin Mass } \\
\text { (gr) }\end{array}$ & \% Rendemen \\
\hline \multirow{3}{*}{ Ethanol } & $70 \%$ & 1.86 & $0.023 \%$ \\
\hline & $80 \%$ & 3.15 & $0.040 \%$ \\
\hline & $90 \%$ & 4.74 & $0.060 \%$ \\
\hline \multicolumn{4}{|l|}{ Beet } \\
\hline \multirow{3}{*}{ Ethanol } & $70 \%$ & 1.75 & $0.025 \%$ \\
\hline & $80 \%$ & 2.25 & $0.038 \%$ \\
\hline & $90 \%$ & 3.14 & $0.054 \%$ \\
\hline \multicolumn{4}{|l|}{ Duwet } \\
\hline \multirow{3}{*}{ Ethanol } & $70 \%$ & 1.25 & $0.021 \%$ \\
\hline & $80 \%$ & 2.27 & $0.035 \%$ \\
\hline & $90 \%$ & 3.30 & $0.052 \%$ \\
\hline
\end{tabular}

Based on observational data, the test results can be seen that extaraksi with solvent concentration variation shows the mass condition of anthocyanins and the percentage of yield will be greater in experiments with the highest solvent concentration of $90 \%$. The extraction results were percent yield of $0.060 \%$ and anthocyanin mass of $4.74 \%$ for sweet potatoes, $0.054 \%$ percent yield and anthocyanin mass $3.14 \%$ for beet tuber and $0.052 \%$ yield and $3.30 \%$ anthocyanin mass for duwet.

The opposite thing happens at a low solvent concentration of $70 \%$. The test results showed that with a low solvent concentration level, the extraction results were also low at $0.023 \%$ for yield and $1.86 \%$ for the anthocyanin mass in sweet potatoes. Also $0.025 \%$ yield and $1.75 \%$ anthocyanin mass in beet tuber and $0.021 \%$ yield percentage and $1.25 \%$ anthocyanin mass for duwet. Thus it can be concluded that the greater the solvent concentration, the higher the mass of anthocyanin and the yield produced. 


\subsection{Effect of Solvent Concentration on Anthocyanin Mass and Rendement}

Table 7. Anova Test on The Effect of Solvent Concentration on Antosinain Mass

\begin{tabular}{|l|r|r|l|l|l|l|}
\hline $\begin{array}{l}\text { Source of } \\
\text { Variation }\end{array}$ & \multicolumn{1}{|l|}{ SS } & \multicolumn{1}{|l|}{ df } & \multicolumn{1}{c|}{ MS } & F & P-value & F crit \\
\hline $\begin{array}{l}\text { Between } \\
\text { Groups }\end{array}$ & 254.2474 & 8 & 31.78093 & 173.1 & 0.000193 & 7.70 \\
\hline Within Groups & 641.0884 & 9 & 71.23204 & & & \\
\hline Total & 895.3358 & 17 & & & & \\
\hline
\end{tabular}

From the results of the analysis using ANOVA test for the effect of solvent concentration on the anthocyanin mass it can be concluded that there were a significant effect of the amount of solvent concentration on anthocyanic mass, where the greater the solvent concentration, the higher the anthocyanin mass will be formed. This can occur because of the large concentration of alcohol that will bind anthocyanins better. So that the resulting mass of anthociani will be even greater. From the results of the calculation of statistical tests it can be seen that the magnitude of the variation in solvent concentration affecting the formation of the antosynin period is 895.3358 .

Table 8. ANOVA Test Effect of Solvent Concentration on Rendement

\begin{tabular}{|c|c|c|c|c|c|c|}
\hline $\begin{array}{c}\text { Source of } \\
\text { Variation }\end{array}$ & $\boldsymbol{S S}$ & $\boldsymbol{d f}$ & $\boldsymbol{M S}$ & $\boldsymbol{F}$ & $\boldsymbol{P}$-value & $\boldsymbol{F}$ crit \\
\hline Between Groups & 300.9708 & 8 & 37.62135 & 191.8 & $0: 001$ & 7708 \\
\hline Within Groups & 29071.2 & 9 & 3230.133 & & & \\
\hline & & & & & & \\
\hline Total & 29372.17 & 17 & & & & \\
\hline
\end{tabular}

As for the analysis of the effect of solvent concentration on yield using ANOVA test results were also obtained where there was a significant effect in the amount of yield. In other words, the higher the concentration level of the solution, the higher the yield level will be produced. This can be seen through the test results that show the amount of 29372.17 Variations that can encourage changes in yield as a result of solution concentrations.

\subsection{Quality of Media Test Borax and Formalin}

The qualitative test procedure is performed by soaking the media of formalin and borax testers into formalin solution, borax and water solution. From the test results, the three testers media formaldehyde and borax are extracted using a solvent variation $(70 \%, 80 \%$ and $90 \%$ ) were able to detect the content of formaldehyde and borax well.

\section{Conclusion}

Based on the results and discussion of the problem can be concluded: 1)purple sweet potato, beetroot and duwet can be used as an indicator for testing formaldehyde and borax content in food by extracting the anthocyanin substances in the plant,2) the higher the concentration of solvent will have a significant effect on the high mass of anthocyanins, 3) the higher the concentration of the solvent will have a significant effect on the high 
percentage of rendement yield, and 4) media tester using solvent variations $(70 \%, 80 \%$ and $90 \%$ ) are able to detect formalin and borax well.

\section{References}

1. Astawan, Made. Mengenal formalin dan bahayanya (Jakarta, Penebar swadaya, 2009)

2. Khamid, I.R. Bahaya boraks bagi kesehatan. (Jakarta, Penerbit Kompas, 2006)

3. Reuss G, W. Disteldorf, AOGamer (2005)

4. Hambali, Mayasari, Noermansyah. Journal of Chemical Engineering Sriwijaya University 20, 2 (2014)

5. N. Richana, Ubi kayu dan ubi jalar, (Bogor, NUANSA CENDIKA, 2009) 